\title{
Problem dan Upaya Pemberdayaan Mudarabah Untuk Meningkatkan Pengembangan Sektor Usaha Mikro di Wilayah Eks Karesidenan Kediri
}

\author{
Zainudin \\ ${ }^{1}$ Universitas Islam Negeri Sayyid Ali Rahmatullah Tulungagung \\ zainudinfaruq@gmail.com
}

\begin{abstract}
This study aims to examine more closely the problem of mudarabah in Islamic financial institutions, and then create patterns of empowerment so that this mudarabah model truly finds its noble identity as an Islamic financial cooperation system that provides increased welfare for the weak. The research used is field research and the type of qualitative research. The research location is the ex-residence of Kediri. The research subjects are the managers of Islamic financial institutions. Sampling using purposive sampling method. Data obtained from observations, documentation and in-depth interviews with informants. The results of the study indicate that the problems that arise from these policies are resolved in different ways according to the policies of the financial institutions themselves. Then, for empowerment, it is necessary to pay attention to the following things: (a) modifying mudarabah as needed, $(b)$ oriented to ease and flexibility, (c) oriented to empowerment not profit, (d) being aggressive and picking up the ball, (e) doing classification of the economic level of prospective customers, (f) carrying out intensive assistance, $(g)$ seeking funds from the government's microcredit program, and $(h)$ trying to establish a deposit insurance institution.
\end{abstract}

Keywords: mudarabah problems, mudarabah empowerment, sharia microfinance institutions

\section{ABSTRAK}

Penelitian ini bertujuan untuk mencermati lebih seksama problem mudarabah dalam lembaga keuangan syariah, dan kemudian membuat pola-pola pemberdayaan sehingga model mudarabah ini benar-benar menemukan jati diri keluhurannya sebagai sistem kerjasama keuangan Islam yang memberikan peningkatan kesejahteraan bagi masyarakat lemah. Penelitian yang digunakan merupakan field research dan jenis penelitian kualitatif. Untuk lokasi penelitiannya wilayah eks-karesidenan Kediri. Subyek penelitian yakni para pengelola lembaga keungan syariah. Pengambilan sampel menggunakan metode purposive sampling. Data diperoleh dari hasil observasi, dokumentasi dan wawancara mendalam terhadap informan. Hasil penelitian menunjukkan bahwa problem-problem yang muncul dari kebijakan-kebijakan tersebut diselesaikan dengan cara yang berbeda-beda sesuai dengan kebijakan dari lembaga keuangan sendiri. Kemudian, untuk pemberdayaannya perlu memperhatikan hal-hal berikut: (a) memodifikasi mudarabah sesuai kebutuhan, (b) berorientasi pada kemudahan dan keluwesan, (c) berorientasi pada pemberdayaan bukan keuntungan, (d) bersikap agresif dan menjemput bola, (e) melakukan klasifikasi tingkat ekonomi calon nasabah, (f) melaksanakan pendampingan secara intensif, $(\mathrm{g})$ berupaya mencari dana dari program kredit mikro pemerintah, dan (h) berusaha membuat lembaga penjamin simpanan.

Kata kunci: problem mudarabah, pemberdayaan mudarabah, lembaga keuangan mikro syariah 


\section{PENDAHULUAN}

Keragaman kehidupan manusia merupakan ketentuan Tuhan. Keragaman tersebut tidak hanya pada hal-hal yang bersifat fisik, budaya, keyakinan, bahasa dan sebagainya, tetapi juga keragaman dalam status dan tingkat ekonomi. Dalam tingkatan ekonomi ini, Tuhan telah membagi kehidupan manusia dalam dua klasifikasi, yaitu; kelompok yang memiliki kelebihan dana dan kelompok yang kekurangan dana. Terkait dengan ini, Islam memerintahkan kepada umat Islam melalui banyak ayat dan hadis bahwa orang kaya harus peduli dan membantu orang-orang yang miskin dan tidak mampu. Salah satu doktrin yang secara tegas dinyatakan dalam Al-Qur'an dan telah dpraktikkan Nabi S.A.W. dan para sahabatnya adalah praktik bisnis kerjasama yag disebut dengan mudarabah. Kerjasama mudarabah adalah kesepakatan antara pemilik dana dengan pekerja dalam mengelola usaha tertentu di mana jika terjadi keuntungan maka keuntungan tersebut dibagi bersama dan jika terjadi kerugian dilimpahkan kepada pemilik modal. Karekater kerjasama mudarabah ini, karenanya, memiliki nilai manfaat yang sangat besar. Makna filosofis yang dipesankan melalui kerjasama ini adalah terjadinya proses pemberdayaan yang menempatkan pemilik modal sebagai agen pemberdaya dan pekerja sebagai obyek yang diberdayakan. Kerjasama mudarabah merupakan sarana pemberian kesempatan kalangan kaya membantu kalangan lemah dengan tujuan agar golongan yang lemah ini dapat hidup lebih sejahtera. Karena itu, mudarabah merupakan salah satu model kerjasama Islam yang mempunyai nilai filosofis luhur, yaitu solidaritas golongan pemilik modal terhadap golongan kekurangan (Ibn 'Abidin, 1987 juga dalam AL-Kasani, 1996).

Namun, dalam kenyataannya, di Lembaga Keuangan Syariah, baik berjenis bank, maupun Kopsyah/BMT, produk pembiayaan mudarabah belum dapat merealisasikan cita-cita luhur dan peran strategis tersebut. Ini dibuktikan dengan rendahnya perbandingan antara produk mudarabah dengan produk berakad jual beli (murabahah). Sumiyanto, dalam penelitiannya, tahun 2004, menunjukkan bahwa perkembangan produk pembiayaan mudarabah hanya mencapai 5\% (Sumiyanto, 2004). Sementara laporan 
dari Ascarya, pertumbuhan produk mudarabah, sampai ujung tahun 2009, masih jauh tertinggal dengan produk murabahah. Mudarabah hanya mencapai 16,3\%, sementara murabahah mencapai 58,9\% (Ascarya, 2009). Meskipun ada peningkatan, namun tidak begitu signifikan. Data tersebut menunjukkan produk mudarabah belum diberdayakan secara optimal. Bahkan dari besaran persentase tersebut belum dilihat sejauhmana mudarabah memberikan peningkatan kalangan pengusaha kecil, sebab umumnya pembiayaan mudarabah diberlakukan lembaga keuangan syariah hanya pada pengusaha besar, mapan dan minim risiko (Cecep Maskanul Hakim, http://www.vibiznews.com/1new/knowle dge/syariah/Problem Pengembangan Produk dalam bank Syariah.pdf).

Kecilnya persentase tersebut, tidak semata karena minat masyarakat rendah, namun disisi lain, pihak lembaga sendiri khawatir dalam menghadapi risiko, kerugian dan "keribetan" yang muncul dalam aplikasi mudarabah. Penelitian Warde (1999), Khalil, Rickwood dan Muride (2000), Karim (2000), Sumiyanto (2004) dan Muhammad (2006) merekomendasikan lembaga keuangan syariah untuk melakukan pengetatan pada dua aspek; karakter calon nasabah dan jenis usaha disampaikan dalam Kajian Riset tentang concept notes. Selain itu, dalam studi lain juga dijelaskan bahwasannya penerapan aqad mudarabah yang kurang efektif dilembaga keuangan juga berdampak pada profitabilitas bank syariah yang tidak signifikan dan kurang begitu memberikan hasil yang memuaskan dibandingkan dengan penerpan akad lainnya (Taudlikhul Afkar, 2017: 349).

Dengan diketatinya aspek usaha dan karakter dan integritas individu ini yang dilakukan secara formalistik, hirarkhis, dan institusionalistis, nampaknya tidak akan membuat mudarabah ini menjadi bagian penting dari pemberdayaan masyarakat ekonomi alit, tapi justru menjauhkan mereka dari kesejahteraannya, dan tentu saja ini tidak sesuai dengan cita-cita luhur mudarabah itu sendiri. Bahkan, kondisi ini bisa membuat citra perbankan syariah dalam menciptakan keadilan dan kesejahteraan menjadi hilang, sistemnya bagi hasil yang luhur yang dialternatifkan sebagai pengganti dari sistem bunga menjadi tidak tercapai, karena bank syariah sendiri telah terjebak dalam semangat kapitalisme itu sendiri. 
Oleh karena itu, penelitian ini ingin mencoba mencermati lebih seksama problem mudarabah dalam lembaga keuangan syariah, dan kemudian membuat pola-pola pemberdayaan sehingga model mudarabah ini benarbenar menemukan jati diri keluhurannya sebagai sistem kerjasama keuangan Islam yang memberikan peningkatan kesejahteraan bagi masyarakat lemah.

\section{LANDASAN TEORI}

Akad mudarabah, sebagai sebuah produk perbankan syari'ah yang mempunyai potensi besar untuk menggerakkan sektor produksi, banyak dilakukan oleh para peneliti baik dalam negeri maupun luar negeri. Namun, dari beberapa hasil penelitian tersebut yang memusatkan kajian pada permasalahan yang timbul dari pembiayaan mudarabah tidaklah banyak. Dari penelusuran penulis, setidaknya ada beberapa hasil penelitian yang mencoba mencari akar persoalannya. Warde (1999) menemukan bahwa permasalahan pembiayaan mudarabah terletak pada adverse selection (kesalahan memilih) dan moral hazard (kredibilitas moral) nasabah. Dan untuk mengantisipasinya, menurutnya, bank harus melakukan pengetatan prosedur pembiayaan dan memonitoring secara optimal usaha nasabah (Ibrahim Warde, 1999). Hampir senada dengan Warde, Khalil, Rickwood dan Muride (2000) menyimpulkan bahwa resiko pembiayaan mudarabah didominasi oleh faktor moral hazard, adverse selection dan discreationary power (tidak adanya kuasa melakukan kreasi atas usaha) (Abdel Fatih AA Khalil, 2000). Terkait moral moral hazard, Bambang (2016) memberikan pernyataan lain yakni moral hazard dapat di atasi salah satunnya dengan menerapkan kontribusi dana oleh mudharib. Selain itu mudharib juga diminta memberikan kontribusi atas kerugian yang mungkin terjadi ketika akad mudarabah diterapkan (Bambang Waluyo, 2016: 200).

Secara lebih detail dan mekanis, Karim (2000) memberikan laporannya bahwa mesti ada mekanisme incentive compatible constraints bagi bank dalam pembiayaan mudarabah. Melalui mekanisme ini, menurutnya, dapat mendudukan persoalan secara proporsional dan rasional antara kepentingan bank dan nasabah. Mekanisme ini diwujudkan dalam beberapa indikator, yaitu; (a) penetapan porsi modal, (b) resiko operasi bisnis 
minimal, (c) bisnis yang dibiayai memiliki laporan keuangan, dan (d) bisnis memiliki biaya tak terkontrol rendah (Adiwarman A Karim, 2000).

Tidak jauh berbeda dengan sebelumnya, Sumiyanto (2004) juga menyimpukan bahwa atribut yang menjadi pertimbangan bank atas nasabah dalam transaksi pembayaan mudarabah adalah track record yang baik, pengusaha punya keahlian, pengusaha dapat mengoreksi usaha, dan pengusaha memiliki usaha. Sedangkan atribut terkait jenis proyek yang dipertimbangkan adalah memiliki resiko kegagalan minimal, menerapkan sistem akuntansi, memberikan return secara pasti, dan biaya pemantauan relatif kecil. Beberapa hal tersebut, menurutnya, menjadikan minat bank terhadap pembiayaan mudarabah sangat kecil (5\%), atau tidak menarik bagi lembaga untuk dibiayai (Sumiyanto, 2004). Apa yang ditemukan dari tulisan-tulisan di atas, nampaknya cenderung melihat persoalan aplikasi pembiayaan mudarabah dari sisi nasabah. Nasabah nampaknya diposisikan sebagai obyek yang perlu diperbaiki dari sebuah hubungan kemitraan antara kreditur dan debiturnya. Dari sisi kedirian nasabah sendiri, penelitian tersebut menyimpulkan bahwa adverse selection, moral hazard, discreationary power, dan tidak adanya kecakapan akuntansi nasabah, merupakan faktor yang dapat mengganggu keberhasilan pembiayaan. Sedangkan dari sisi proyeknya, penelitian tersebut menunjukkan bahwa jenis bisnis harus mempunyai resiko rendah atau prospektif, bisnis mempunyai biaya tak terkontrol rendah, dan bisnis memiliki laporan keuangan.

Sementara penelitian yang mencoba mengevaluasi dari sisi lembaga pembiayaan dapat ditemukan pada tulisannya Dharmawangsa (2003). Ia meneliti praktik-praktik gharar yang muncul dalam aplikasi pembiayaan, khususnya dari sisi lembaga. Penelitian ini menemukan bahwa prilaku gharar lembaga dijumpai karena dua hal, yaitu; (a) adanya incomplete information dari usaha yang akan ditransaksikan, dan (b) kurangnya pengetahuan (ignorane, juhala') sehingga tidak memiliki kecakapan dalam melakukan transaksi. Karena masalah itu, penelitian ini menyimpulkan bahwa ketidakberhasilan pembiayaan mudarabah karena ketidaktahuan lembaga mengaplikasikan mudarabah secara baik, bahkan dengan itu dapat menyebabkan ketidakadilan 
Ad-Deenar: Jurnal Ekonomi dan Bisnis Islam, VOL: 5/NO: 02

DOI : 10.30868/ad.v5i02.1739

dalam sebuah kerjasama

(Dharmawangsa, 2003).

Dari survey lietatur di atas setidaknya pembicaraan tentang problematika pembiayaan mudarabah dalam perbankan syari'ah dapat dipetakan menjadi 3 bagian. Pertama, problematika yang lahir dari sisi nasabah dan usaha yang dikelolanya, dimana diketahui bahwa nasabah sebagai peminjam dana seringkali terdiri dari individu-individu yang yang mempunyai latar belakang beragam sehingga harus diketati agar tidak salah pilih (adverse selection), dipertanyakan kredibiltas moralnya (moral hazard), kurang kreatif dalam pengelolaan usahanya (discreationary power) dan kurang cakap dalam pembuatan laporan usaha (akuntansi). Sedangkan dari sisi atribut usahanya, ditemukan usaha tersebut haruslah jenis bisnis harus mempunyai resiko rendah atau prospektif, bisnis mempunyai biaya tak terkontrol rendah, dan bisnis memiliki laporan keuangan. Kedua, dari sudut pandang kelembagaannya yang terfokus pada kajiannya tentang intervensi lembaga terhadap usaha nasabah, adanya jaminan, pembagian bagi hasil, dan penentuan masa kontrak. Praktik tersebut
P-ISSN: 2356-1866

E-ISSN: 2614-8838

diaplikasikan secara kurang tepat sebagaimana teori fiqhnya. Hal itu disebabkan karena lembaga tidak mempunyai informasi yang mamadai (incomplete informastion) dan tidak memiliki pengetahuan yang cukup (ignorance, juhala') sehingga lembaga tidak mempunyai kecakapan mengelola mudarabah. Dan ini rawan terjerumus dalam praktik gharar. Ketiga, dari perspektif motivasi nasabah dalam memilih produk mudarabah. Motivasi nasabah disemangati tidak saja oleh faktor agama (keakhiratan) yang berarti motivasi emosional atau ideologis, tetapi juga faktor keduniawian yang terwujud dalam fleksibilitas birokrasi, kualitas layanan, reputasi lembaga, praktek good social responsibility dan harga produk. Faktor-faktor non keagamaan ini menunjukkan bahwa motivasi nasabah dapat dikatakan keduniawian atau rasional.

Pemberdayaan masyarakat pada dasarnya merupakan proses untuk membuat masyarakat menjadi berdaya. Setiap anggota masyarakat dalam sebuah komunitas sebenarnya memiliki potensi, gagasan serta kemampuan untuk membawa dirinya dan komunitasnya untuk menuju ke arah yang lebih baik, 
namun potensi itu terkadang tidak bisa berkembang disebabkan faktor-faktor tertentu. Untuk menggerakkan kembali kemandirian masyarakat dalam pembangunan di komunitasnya, maka diperlukan dorongan-dorongan atau gagasan awal untuk menyadarkan kembali peran dan posisinya dalam kerangka untuk membangun masyarakat madani. Proses penyadaran masyarakat tersebut dilakukan melalui konsepkonsep pengem- pengembangan kapasitas. Pengembangan kapasitas masyarakat adalah bentuk dari upaya pengembangan pengetahuan, sikap dan kete- rampilan masyarakat agar dapat berperan serta aktif dalam menjalankan pembangunan secara mandiri dan berkelanjutan.

Pengembangan kapasitas masyarakat pa da hakikatnya merupakan usaha meningkatkan kemampuan masyarakat itu sendiri, sehingga kegiatan tersebut seharusnya mendapat dukungan dan peran serta aktif dari masyarakat itu sendiri. Apabila masyarakat sebagai pihak yang paling berkepentingan belum memahami secara betul makna dari pengembangan kapasitas itu sendiri dan tidak memberikan tanggapan secara positif terhadap upaya-upaya pengembangan kapasitas yang dilaksanakan maka bisa dipastikan upaya tersebut tidak akan berdaya guna dan berhasil sesuai tujuan yang ingin dicapai. Wilson menjelaskan empat tahapan dalam pemberdayaan masyarakat, yaitu tahap penyadaran, tahap pemahaman, tahap pemanfaatan, dan tahap pembiasaan. Tahap pembiasaan adalah tahapan paling akhir dalam proses pemberdayaan, dimana masyarakat telah terbiasa untuk terlibat secara aktif dalam pembangunan di lingkungannya, karena pada pada dasarnya hasil atau keluaran yang didapatkan adalah untuk kepentingan mereka sendiri (Terry Wilson, 1996).

Berdasarkan beberapa pengertian di atas, secara umum pemberdayaan masyarakat dapat diartikan sebagai upaya untuk memulihkan atau meningkatkan kemampuan suatu komunitas untuk mampu berbuat sesuai dengan harkat dan martabat mereka dalam melaksanakan hak-hak dan tanggungjawabnya selaku anggota masyarakat. Dengan adanya pemberdayaan, diharapkan masyarakat memiliki budaya yang proaktif untuk kemajuan bersama, mengenal diri dan lingkungannya serta memiliki sikap bertanggung jawab dan memposisikan 
dirinya sebagai subjek dalam upaya pembangunan di lingkungannya.

Menurut Wilson terdapat 7 tahapan dalam siklus pemberdayaan masyarakat. Tahap pertama yaitu keinginan dari masyarakat sendiri untuk berubah menjadi lebih baik. Pada tahap kedua, masyarakat diharapkan mampu melepaskan halangan-halangan atau faktor-faktor yang bersifat resistensi terhadap kemajuan dalam dirinya dan komunitasnya. Pada tahap ketiga, masyarakat diharapkan sudah menerima kebebasan tambahan dan merasa memiliki tanggungjawab dalam mengembangkan dirinya dan komunitasnya. Tahap keempat lebih merupakan kelanjutan dari tahap ketiga yaitu upaya untuk mengembangkan peran dan batas tanggungjawab yang lebih luas, hal ini juga terkait dengan minat dan motivasi untuk melakukan pekerjaan dengan lebih baik. Pada tahap kelima ini hasil-hasil nyata dari pemberdayaan mulai kelihatan, dimana peningkatan rasa memiliki yang lebih besar menghasilkan keluaran kinerja yang lebih baik. Pada tahap keenam telah terjadi perubahan perilaku dan kesan terhadap dirinya, dimana keberhasilan dalam peningkatan kinerja mampu meningkatkan perasaan psikologis di atas posisi sebelumnya. Pada tahap ketujuh masyarakat yang telah berhasil dalam memberdayakan dirinya, merasa tertantang untuk upaya yang lebih besar guna mendapatkan hasil yang lebih baik. Siklus pemberdayaan ini menggambarkan proses mengenai upaya individu dan komunitas untuk mengikuti perjalanan ke arah prestasi dan kepuasan individu dan pekerjaan yang lebih tinggi. Berdasarkan faktor-faktor tersebut di atas, maka hasil dari sebuah upaya pemberdayaan akan sangat tergantung dari kondisi masyarakat dan peran serta semua stakeholder yang terlibat dalam program pemberdayaan tersebut.

Pemberdayaan masyarakat harus dilaksanakan baik pada tataran sistem, kelembagaan dan individu. Peningkatan kapasitas kelembagaan berarti usaha untuk meningkatkan peran dan mengembangkan tata kelembagaan di tingkat masyarakat yang mampu mewadahi setiap gagasan, usulan dan aspirasi dari masyarakat untuk kemajuan dalam komunitasnya. Peningkatan kapasitas kelembagaan ini meliputi usaha penyadaran masyarakat untuk menyusun norma-norma dan aturan-aturan yang menyangkut pola perilaku masyarakat yang mana keluaran dari usaha ini adalah 
terbentuknya lembaga-lembaga berbasis komunitas untuk pembangunan dalam lingkungannya. Peningkatan kapasitas juga meliputi usaha untuk meningkatkan kemampuan manajerial dan berorganisasi masyarakat dalam upaya mewujudkan tata kelembagaan yang lebih partisipatif dan transparan.

\section{METODE PENELITIAN}

\begin{tabular}{lll}
\multicolumn{2}{c}{ Penelitian yang digunakan } \\
merupakan field research dan jenis \\
penelitian kualitatif. Untuk lokasi
\end{tabular}
penelitiannya mengambil wilayah ekskaresidenan Kediri. Wilayahnya meliputi kota Kediri, kabupaten Kediri, Kota Blitar, kabupaten Blitar, kabupaten Tulungagung, kabupaten Nganjuk, kabupaten Trenggalek. Subyek dalam penelitian ini yakni para pengelola lembaga keungan syariah khususnya hal hal yang terkait penelitian seperti BMT atau Koperasi syariah diwilayah ekskaresidenan Kediri. Pengambilan sampel wilayah dilakukan dengan metode purposive sampling supaya dapat mewakili golongan tersebut. Dalam penelitian ini, sumber data yang diambil berasal dari sebuah kata-kata dan perilaku dari pengelola lembaga keungan syariah. Selain itu, pengumpulan data yang tertulis dan informasi yang diambil dari beberapa informan seperi karyawan tiap lembaga-lembaga tersebut menjadi data tambahan yang mungkin diperlukan saat penelitian. Teknik pengecekan data (triangulasi) dilakukan dengan sasaran kepada para pengusaha yang menjadi nasabah dilembaga keuangan tersebut. Data diperoleh dengan mengolah hasil observasi, dokumentasi dan wawancara mendalam terhadap informan. Data yang diambil tersebut berupa data kualitatif yang banyak berbentuk kata-kata baik dalam bentuk lisan atau tulisan dan juga berupa dokumen, arsip dan foto yang dikumpulkan saat proses penelitian berlangsung. Teknis analisis data yang dilakukan yakni deskriptif kualitatif yang bersifat induktif. Analisisnya mengikuti alur reduksi data, penyajian data dan verifikasi.

\section{PEMBAHASAN}

\section{Problem-problem dan Solusi yang Diberikan}

Problem-problem yang dialami BMT-BMT di eks Karesidenan Kediri dalam mengaplikasikan mudarabah sebagaimana dalam wawancara dengan pengelola BMT Sahara Tulungagung antara lain; (a) resikonya tinggi, (b) nasabah sering tidak jujur, (c) nasabah 
tidak telaten menabung, (d) ada ruginya, ada untungnya; fluktuatif, (e) masyarakat belum paham mudarabah, (f) masyarakat terbiasa dengan sistem riba (bunga) yang tidak ribet disampaikan oleh pengelola KJKS Kota Kediri, (g) kurang diminati masyarakat hal ini disampaikan pengelola BMT Syariah Pare Kediri, (h) sulitnya mengecek latar belakang calon nasabah disampaikan pengelola BMT al-Ridho Trenggalek, (i) pihak ketiga terlambat bayar, (j) keuntungan dibawah standar dari jumlah modal yang diinvestasikan, (k) nasabah kurang mematuhi aturan sehingga lembaga mengeluarkan tenaga dan biaya, (1) nasabah tidak tertib dalam administrasi, (m) terjadi penggelapan barang, (n) terjadi kecelakaan yang mengakibatkan kerusakan pada sarana usaha (pengelola BMT Sahara Tulungagung).

Namun, problem-problem itu tidak dibiarkan, BMT selalu mencari jalan keluar untuk memecahkan problem tersebut. Beberapa solusi yang diberikan secara umum adalah: (a) nasabah diharuskan menabung sesuai kemampuan asalkan rutin, (b) semua kemacetan yang membuat dana modal pembiayaan mudarabah hilang atau berkurang dilunasi dengan dana ZIS (Pengelola
BMT Sahara), (c) BMT secara terus menerus memberikan pemahaman kepada masyarakat tentang model mudarabah yang bagi lembaga menuntut kesadaran penuh nasabah disampaikan oleh Pengelola KJKS Kota Kediri, (d) menentukan calon nasabah secara lebih selektif, (e) BMT harus secara kontinyu meningkatan intensitas penagihan, (f) LKS memberikan kelonggaran bagi nasabah bermasalah untuk membayar semampunya, nyicil, (g) BMT membantu pemasaran produk usaha nasabah, (h) LKS membantu administrasi nasabah termasuk pencatatan uang keluar dan masuk, penghitungan laba dan rugi, (i) BMT membantu mengantarkan barang pesanan, sekaligus mengecek dan mengawasi, dan (k) BMT membantu bukan saja material tapi juga moril (immaterial), agar nasabah tetap bersemangat (pengelola KSU Syariah Muhammadiyah Blitar).

Apa yang disebutkan sebagai problem sebagaimana di atas, nampaknya hanya dari sisi nasabah. Problem yang bersifat internal dari BMT tidak disebutkan. Padahal sangat mungkin, pihak BMT sendiri juga bermasalah, seperti yang pernah diteliti oleh Martowijoyo bahwa Martowijoyo, 
lemahnya kinerja lembaga keuangan dapat dilihat dari 3 aspek, yaitu; (a) rendahnya tingkat pelunasan kredit, (b) rendahnya moralitas aparat pelaksana, dan (c) rendahnya tingkat mobilitas dana masyarakat. Kelemahan tersebut membawa konsekuensi pada tidak berlanjutnya lembaga keuangan yang terbentuk setelah program selesai. Akibatnya, peserta program umumnya akan kembali mengalami kekurangan modal (S Martowijoyo, 2002).

Oleh karena itu, nampaknya memang pihak BMT lebih menitikberatkan pada nasabah dalam konteks dari mana problem itu muncul. Artinya, bahwa jika pembiayaan mudarabah ini hendak diterapkan, maka harus ditanyakan kepadamasyarakat terlebih dahulu apakah mereka siap untuk jujur, tidak berbohong, disiplin dalam membayar tanggungan, membagi keuntungan secara rutin, membuat laporan pembukuan, dan sebagainya. Sementara kalau BMT sudah siap semuanya, dengan prosedur, mekanisme dan sumber daya manusianya. Oleh karena itu, secara makna tersirat bahwa jika ada terjadi problem dalam penerapan mudarabah, maka tentu saja pihak nasabah yang bertanggung jawab.

\section{Upaya BMT Melakukan Pemberdayaan}

Praktik pemberdayaan yang dilakukan BMT di eks Karesidenan Kediri kurang sesuai dengan harapan. Karena praktik tersebut hanya didasarkan pada tiga orientasi, yaitu; orientasi pada hasil, orientasi pada ketertiban administrasi, dan orientasi pada pemantauan tidak terjadinya moral hazard. Pertama, orientasi pada hasil. Hampir semua BMT di eks Karesidenan Kediri dalam memberikan pembiayaan mudarabah ini selalu melihat apakah usaha yang dilakukan nasabah itu prospektif tidak. Dan lebih serius lagi apakah usaha tersebut mendatangkan hasil atau tidak. Keseriusan akan hasil ini sangat tampak dalam beberapa persyaratan dan ketentuan umum. Sebagian besar BMT meninjau terlebih dahulu secara langsung di lokasi usaha maupun melalui wawancara untuk memastikan bahwa usaha yang akan dibiayainya dapat mendatangkan keuntungan. Apalagi dalam banyak hal, informasi terkait keuntungan usaha ini harus dijelaskan oleh nasabah di awal kontrak. Artinya bahwa jika usaha tersebut tidak mendapatkan keuntungan maka usaha tersebut bisa dipastikan tidak mendapatkan dana pembiayaan. Tapi jika 
nasabah bisa memastikan keuntungan atas usahanya, maka dana akan dicairkan. Bahkan hampir semua BMT juga menetapkan bahwa kejelasan keuntungan tersebut adalah sebagai dasar bagi penghitungan persentase bagi hasil bagi kedua pihak. Jadi dalam hal ini, BMT tidak membiarkan dulu nasabah mengelola dananya hingga sampai mendapatkan keuntungan atas usahanya, tetapi harus dipastikan dulu berapa jumlah keuntungan tiap bulan sebelum mereka menggunakannya.

Mengenai hal tersebut, bagi kelompok yang sudah mempunyai usaha mapan dan sudah mendapatkan keuntungan secara rutin, BMT dapat meminta informasi terkait keuntungan yang selama ini diperoleh nasabah sebagai dasar penentuan nisbah bagi hasil. Atau BMT dapat menetapkan hal itu dalam persyaratan pengajuan. Artinya disini, BMT dapat mengedepankan keuntungan, karena usaha yang sudah berjalan. Kasus seperti ini tentunya diperuntukkan bagi calon nasabah yang memang sedang mengembangkan usaha. Sedangkan untuk kelompok masyarakat yang belum punya usaha tetap atau belum punya usaha sama sekali, keuntungan bukan sesuatu yang penting. Yang lebih penting adalah membantu menghidupkan usaha. Ini perlu pendampingan serius dan intens. Dengan kata lain, pihak BMT tidak saja hanya memberikan dana pembiayaan. BMT juga bertanggung jawab untuk terjun langsung ke lapangan melakukan pendampingan atas usaha mereka. Pendampingan dilakukan mulai dari manajemen pengelolaan usaha, modal sampai pada pemasaran. Dalam konteks ini, pihak lembaga berorientasi pada pengabdian murni, bukan keuntungan bisnis.

Kedua, orientasi pada ketertiban administratif. Masalah administrasi, pembuatan laporan atau pembukuan tentang uang masuk dan keluar, serta tentang laporan untung dan rugi merupakan sesuatu yang penting dalam usaha. Dalam penerapan pembiayaan mudarabah beberapa BMT menjadikan pembukuan ini sebagai suatu keharusan. Melalui pembukuan itu, pihak BMT dapat membaca sejauhmana pemanfaatan dana dikelola dengan baik dan rapi. Tujuan utama adanya pembukuan secara tertib ini, oleh pihak BMT, adalah sebagai sarana untuk melihat tingkat perkembangan modal yang diberikan. Secara lebih khusus untuk melihat tingkat keuntungan atau kerugian yang diperoleh. 
Karena dengan adanya pembukuan yang tertib dan rapi, masyarakat tidak bisa berbohong soal keuntungan yang diperoleh. Ketiga, orientasi pada pemantauan tidak terjadinya moral hazard. Semua BMT dalam mengantisipasi adanya moral hazard nasabah dengan cara menetapkan persyaratan bahwa semua calon nasabah harus terlebih dahulu pernah menjadi nasabah di BMT bersangkutan dan juga aktif dan tertib dalam melakukan pembayaran angsuran dan bagi hasil atau margin keuntungan kepada BMT setiap waktu/bulan. Ini dilakukan BMT dalam rangka melihat dan mengukur tingkat kejujuran nasabah. Artinya tingkat kejujuran atau kredibilitas calon nasabah pembiayaan mudarabah diukur dengan keaktifan dan ketertibannya membanyar tanggungannya. Calon nasabah yang telah teruji saat menjadi nasabah di BMT tertentu, dia mempunyai peluang besar untuk mendapatkan pembiayaan mudarabah ketika mereka mengajukan kebutuhannya untuk usaha. Sebaliknya calon nasabah yang tidak disiplin dan tertib dalam membayar tanggungan selama dia menjadi nasabah BMT tertentu, maka peluangnya sangat kecil, bahkan ada BMT yang langsung menolaknya. Ada juga BMT yang tidak saja melihat dari track record-nya selama menjadi nasabah, tetapi dengan cara meminta pendapat dari masyarakat sekitar rumah dan lokasi usaha calon nasabah.

Dengan beroeientasi pada tiga aspek di atas akan sulit produk pembiayaan mudarabah bisa menjadi alat pemberdaya ekonomi masyarakat. Oleh karena itu, untuk melakukan pemberdayaan yang sesungguhnya yang tujuan akhirnya perubahan ekonomi bagi masyarakat dari sejahtera menjadi sejahtera, maka BMT harus memperhatikan hal-hal sebagai berikut:

\section{a. Memodifikasi Mudarabah sesuai Kebutuhan}

Memodifikasi mudarabah sesuai dengan kebutuhan dengan tanpa meninggalkan nilai luhur sangat bisa dilakukan, apalagi tidak ada aturan yang ketat terkait dengan operasional mudarabah. Sebagaimana dijelaskan pada pembahasan sebelumnya, mudarabah dipraktikkan dalam sejarah transaksi Islam secara beragam. Bahkan beberapa ulama menyatakan bahwa doktrin tentang mudarabah ini tidak ditemukan rujukannya (Ibn Hazm, Al-Muhalla). Mudarabah hanyalah praktik evolusi suatu kerjasama yang terus menerus 
mengalami perubahan sesuai dengan kebutuhan transaksi bisnis saat itu. Demikian juga dipertegas oleh Abraham L Udovitch, bahwa di masyarakat Eropa, kerjasama mudarabah lebih dikenal dengan istilah commenda (Abraham L Udovitch, 2008: 238). Dengan demikian, BMT dapat mengembangkan produk mudarabah ini melalui berbagai sektor yang dibutuhkan masyarakat kecil. Sektor pertanian, peter- nakan, perdagangan, kerajinan, konveksi, proyek pembangunan dapat dilakukan dengan model mudarabah ini. yang penting BMT memberikan suntikan modal kepada peng- usaha kemudian hasil usahanya dibagi dua sesuai dengan persentase yang disepakati di awal kontrak. Namun tentunya tidak sampai disitu. Karena BMT itu sejak awal bercita-cita melayani masyarakat miskin yang terping- girkan oleh sistem keuangan formal (B Krishnamurti, 2005), maka BMT harus melakukan pendampingan agar cita-cita mudarabah yang berupa terbangun- nya nilai solidaritas golongan kaya dan surplus dana terhadap masyarakat miskin yang minus dana, terlaksana dengan baik.

\section{b. Berorientasi pada Kemudahan dan Keluwesan}

Sebagai lembaga keuangan mikro, BMT merupakan lembaga keuangan yang bersentuhan langsung dengan masyarakat dan sektor riil. Yang dihadapi BMT adalah para pengusaha kecil kelas kampung yang kebanyakan masih belum terbiasa dengan urusan yang bersifat formal dan administratif. Namun jika sektor usaha kecil di pedesaan ini tumbuh dengan baik, maka secara langsung akan berpengaruh pada pertumbuhan ekonomi dalam skala nasional. Karena itulah BMT harus bersikap membantu dengan cara mem- berikan kemudahan-kemudahan dan kelu- wesan. Kemudahan dan keluwesan ini bisa diwujudkan dengan persyaratan yang tidak memberatkan masyarakat. Prosedur yang mudah, luwes dan terjangkau namun tetap memberikan kesan serius kepada masyarakat merupakan cara yang baik untuk diterapkan. Terkait dengan jaminan, misalnya, tidak semua masyarakat mempunyai sesuatu yang bisa digunakan sebagai jaminan. Bahkan jaminan ini bagi kebanyakan masyarakat kecil di- anggap sebagai suatu yang menakutkan. Jaminan bisa saja ditiadakan asal usaha nasabah terpantau dengan baik. Karena jaminan hanyalah sebagai pengekang kese- riusan nasabah dalam menggunakan dana pembiayaan. Sepanjang nasabah bisa serius dalam usaha dan terpantau dengan 
baik, nampaknya jaminan menjadi sesuatu yang kurang penting. Demikian juga masalah ketakutan lembaga akan tingkat kejujuran nasabah. Asalkan kesadaran masyarakat kecil bisa ditumbuhkan dengan baik melalui pendekatan yang tepat, kejujuran akan muncul dengan sendirinya. Karena pada prinsipnya masyarakat kecil itu secara naluri ingin membuat hidupnya lebih baik (Terry Wilson, 1996). Oleh karenanya, menjadi sebuah keniscayaan, sebuah lembaga keuangan mikro seperti BMT yang bercita-cita memajukan kesejahteraan masyarakat pedesaan menetapkan prosedur dan persyaratan serta mekanisme yang fleksibel dan kontekstual dengan masyarakat yang dihadapinya (B Krishnamurti, 2005).

\section{c. Berorientasi Pemberdayaan Keuntungan}

Orientasi BMT selama ini memang mengesankan sangat materialistis. Ini bisa dilihat misalnya setiap ada pengajuan pembiayaan dari calon nasabah yang dijadikan pertimbangan utama adalah tingkat keun- tungan yang akan dibagihasilkan. Orientasi akan keuntungan ini seakan-akan mengisyaratkan bahwa BMT ini "juragan” yang tinggal menunggu untung. Berorientasi pada keun- tungan ini sangat tidak mendidik kepada masyarakat. Mestinya yang perlu dipertim- bangkan adalah prospektifitas dan kualitas usaha yang akan dijalani calon nasabah dengan mempertimbangkan sejauhmana pemberdayaan bisa dilakukan dengan jenis usaha tersebut. Keuntungan merupakan hasil akhir dari sebuah usaha pemberdayaan. Pemberda- yaan yang dilakukan dengan baik akan tentu menghasilkan keuntungan yang besar. Oleh karena itu, usaha apapun sebenarnya asalkan kontekstual dengan perkembangan pasar sangat potensial untuk diberdayakan. Dengan menekankan pada pemberdayaan pada setiap pembiayaan, khususnya mudarabah, maka sebenarnya BMT telah mendorong masyarakat kelas bawah untuk beraktivitas ekonomi secara baik dan sungguh-sungguh serta berusaha untuk melakukannya dengan tanpa sia-sia (I Nyoman Sumaryadi, 2005: 87). Jika masyarakat sudah termotivasi, maka BMT mendapatkan dua keuntungan; keuntungan secara material dan keuntungan karena berhasil menggugah semangat masyarakat kecil.

\section{d. Bersifat Lebih Agresif dan Menjemput Bola}


Satu hal yang tidak dilakukan BMT di eks Karesidenan Kediri adalah bersifat agresif dan menjemput bola, mencari nasabah di pelosok pedesaan tanpa menunggu mereka mendatangi kantor. Umumnya BMT tidak melakukannya dikarenakan sifat ketakutan (baca: kehatihatian) BMT dalam mengelola keuangan yang merupakan titipan dari pihak ketiga (deposan). Padahal cara seperti ini merupakan wujud nyata dari keberpihakan BMT terhadap peningkatan kesejahteraan pengusaha kecil. Dalam hal ini, BMT tidak menunggu calon nasabah yang akan mengajukan pembiayaan mudarabah, tetapi pihak BMT mencari para pengusaha yang membutuhkan tambahan modal. Dengan melakukan survey langsung ke lapangan dan melakukan wawancara mendalam dengan mereka, BMT akan mengetahui tingkat kebutuhan modal, secara khusus, dan memahami problem usaha yang dialami masyarakat secara umum. Metode ini sangat sukses diterapkan oleh Muhammad Yunus dalam memberdayakan para pengusaha kecil yang tersebar di sekitarnya. Karena tidak semua masyarakat miskin berkesempatan atau berani datang ke BMT untuk mengajukan permohonan pembiayaan.
Mereka umumnya enggan dan "pakewueh" dengan situasi formal yang ada di kantor. Sehingga usaha mereka tidak ada kemajuan. Dengan cara agresif dan jemput bola, maka sasaran pemberdayaan ekonomi masyarakat akan mencapai tujuan semestinya. Yunus menyebut metode ini dengan "mata cacing", artinya untuk melihat situasi masyarakat dan kebutuhannya akan fasilitas yang menunjang usahanya adalah dengan cara masuk langsung ke dalam komunitas masyarakat miskin, menanyainya langsung kepada mereka dan mencoba memahami apa yang mereka butuhkan (Muhammad Yunus, 2007). Cara ini tentu lebih mengenai sasaran daripada menunggu mereka mendatangi kantor.

\section{e. Klasifikasi Tingkat Ekonomi Calon Nnasabah}

BMT perlu mengklasifikasi calon nasabah terlebih dahulu sebelum memberikan dana pembiayaan mudarabah. Ini penting untuk mengukur sejauhmana pembiayaan itu akan benarbenar bermanfaat bagi mereka. Klasifikasi nasabah, sebagaimana dikonsepkan Marguiret S Robinson, meliputi 3 kelompok, yaitu; (a) nasabah yang merupakan masyarakat yang sangat miskin (the extreme poor) yakni mereka 
yang tidak berpenghasilan dan tidak memiliki kegiatan produktif, (b) nasabah yang merupakan masyarakat yang dikategorikan miskin namun memiliki kegiatan produktif (economically active working poor), dan (c) nasabah yang merupakan masyarakat yang berpenghasilan rendah (lower income) yakni mereka yang memiliki penghasilan meskipun tidak banyak (Marguiret $\mathrm{S}$ Robinson, 1993). Bagi kelompok pertama, mungkin produk pembiayaan mudarabah tidak pas bagi masyarakat, sebab yang dibutuhkan mereka adalah terpenuhinya pangan, subsidi, dan pekerjaan tetap yang tidak membutuhkan modal. Sedangkan bagi kelompok kedua dan ketiga, lebih efektif jika digunakan pendekatan tidak langsung, misal-nya; pemberian modal usaha, pendampingan usaha, penciptaan iklim kondusif bagi pengembangan usaha, dan mensinergikan usaha mereka dengan para pelaku usaha menengah maupun besar. Kelompok kedua dan ketiga ini, tentu tepat jika diberikan pembiayaan mudarabah dan tentunya juga dengan pendampingan yang intensif dari BMT.

\section{f. Pendampingan secara Intensif}

Pendampingan merupakan tindakan dari sebuah pemberdayaan. Apa yang dilakukan BMT di eks Karesidenan Kediri sangat tidak maksimal dalam pendampingan ini. Pendampingan itu harus dilakukan secara total. Pendampingan BMT terhadap pengusaha kecil secara umum dipetakan menjadi 3 wilayah, yaitu; (a) sebelum mereka menjadi nasabah, (b) pada saat menjadi nasabah, dan (c) setelah mereka menjadi nasabah. Sebelum mereka menjadi nasabah, BMT harus bertindak aktif mengobservasi pengusaha kecil secara langsung di lapangan yang benar-benar membutuhkan dana pembiayaan mudarabah. Pada saat mereka menjadi nasabah, BMT juga harus mendampingi secara intensif kegiatan usaha mereka, mengawal, membina dan mengarahkan serta memberikan langkah-langkah strategis yang dapat meningkatkan usaha mereka, termasuk membuka jalur distribusi bagi pemasaran mereka. Sedangkan tahap ketiga, setelah menjadi nasabah, BMT juga tidak tinggal diam, BMT harus mendampingi dalam mengevauasi semua proses, dari mulai awal sampai akhir masa pembiayaan, termasuk mengawal tingkat kemandirian mereka dalam usaha. Pendampingan secara intensif ini dapat menghasilkan pengusaha-pengusaha kecil yang kuat 
yang dapat bertahan dengan iklim ekonomi yang berubah-ubah sehingga pada akhirnya dapat memutus mata rantai kemiskinan selama ini mereka alami (Wilorejo Wirjo Wirjono, 2005).

\section{g. Mencari Dana dari Program Kredit Mikro Pemerintah}

Mencari bantuan dana pemerintahan untuk menyalurkan kredit mikro merupakan aternatif lain dari bantuan dana yang disediakan oleh BMT itu sendiri. Menjadi perantara bagi dana bantuan pemerintah ini dalam menyalurkan kredit mikro ini penting dilakukan BMT, utamanya ketika BMT khawatir akan hilangnya modal pihak ketiga. Pentingnya dana ini adalah BMT bisa menerapkan mudarabah secara lebih ideal, dimana BMT tidak menentukan persentase bagi hasil secara besar. BMT bisa menetapkan porsi bagi hasilnya secara lebih minimalis. Meskipun tanggung jawab BMT sama besarnya dengan memberikan dana yang berasa dari pihak ketiga, namun secara mental BMT lebih tenang, karena tidak ada tuntutan untuk berbagi hasil sesuai porsi yang disepakati dengan pihak ketiga. Di sisi lain, nasabah mudarabah juga akan tenang dan leluasa, karena bisa mendapatkan porsi bagi hasil yang sangat besar.

\section{h. Adanya Lembaga Penjamin Simpanan}

Lembaga Penjamin Simpanan (LPS) bagi aplikasi pembiayaan mudarabah memang sangat diperlukan. Dengan adanya LPS ini BMT mungkin akan lebih leluasa untuk menyalurkan dananya kepada masyarakat, tanpa adanya kekawatiran akan hilangnya modal. Namun, sampai sekarang ini LPS bagi BMT atau koperasi lainnya, oleh pemerintah belum dianggap penting. Ini sangat mungkin dikarenakan, BMT yang payung hukumnya koperasi, dianggap sebagai lembaga keuangan yang menjadikan masyarakat sebagai anggotanya, sehingga adanya LPS kurang penting. Penjaminnya langsung oleh masyarakat sendiri. Bagi BMT, oleh karena itu, penjamin simpanan ini bisa diambilkan dari kelompok orang-orang kaya, orang-orang berpengaruh, para pejabat, atau lainnya, yang siap dan bertanggung jawab pada berlangsungnya proses pembiayaan mudha- rabah. Dalam hal ini, BMT harus mencari lembaga atau sekelompok orang yang mau menjadi penjamin simpanan. Namun jikapun tidak ada LPS, bukan berarti BMT enggan mengaplikasikan pembiayaan mudarabah. Cara terakhir yang umumnya dilakukan BMT dengan menyisihkan sebagian dana ZIS sebagai cadangan untuk 
mengantisipasi ke- mungkinan gagal bayar nasabah mudarabah kiranya perlu didukung dan diteruskan. Namun sayangnya, meskipun BMT telah menjadikan dana ZIS sebagai dana penjamin simpanan, keterlibatan aktif BMT untuk ikut member- dayakan masyarakat ekonomi sulit belum sepenuhnya.

\section{KESIMPULAN}

Makna filosofis mudarabah yang bewujud proses pemberdayaan belum sepenuhnya dipahami oleh pengelola BMT eks Karesidenan Kediri. Hal ini Pemahaman ini berimplikasi pada kebijakan lembaga dalam mengaplikasikannya. Munculnya problem-problem aplikasi dan kebijakan yang kurang berpihak pada nasabah merupakan bagian dari hal tersebut. Praktik pemberdayaan yang hanya berorientasi pada tiga orientasi; hasil, tertib administrasi, dan tidak terjadinya moral hazard sangat jauh dari makna mudarabah yang menyiratkan semangat perubahan kondisi melalui pemberdayaan. Karena itu, semestinya pemberdayaan masyarakat dilakukan BMT dengan cara; memodifikasi mudarabah sesuai kebutuhan, berorientasi pada kemudahan dan keluwesan, berorientasi pada pemberdayaan bukan keuntungan, bersikap agresif dan menjemput bola, melakukan klasifikasi tingkat ekonomi calon nasabah, melaksanakan pendampingan secara intensif, berupaya mencari dana dari program kredit mikro pemerintah, dan berusaha membuat lembaga penjamin simpanan.

\section{DAFTAR PUSTAKA}

Abidin, Ibn. (1987). Radd Al-Mukhtar 'ala Al-Durr Al-Mukhtar. Beirut: Dar Ihya al-Turath.

Afkar, Taudlikhul. (2017). Influence Analysis Of Mudarabah Financing And Qardh Financing To The Profitability Of Islamic Banking In Indonesia, Ajie: Asian Journal of Innovation and Entrepreneurship, 02(03).

Al-Dasuqi. (1989). Hashiyah Al-Dasuqi 'ala Al-Sharh Al-Kabir. Beirut: Dar al-Fikr.

Al-Ghazali, Imam. (1937). AlMustashfa'. Al-Qahirah: alMaktabah al-Tijariyyah al-Kubra.

Al-Jawziyyah, Ibn Qayyim. (1955). 'I'lam Al-Muwaqi'in. Al-Qahirah: alMaktabah al-Tijariyyah al-Kubra.

Ascarya. (2009). The Lack of Profit-andLoss Sharing Financing in Indonesia's Islamic Bank: Revisited.

Brosur Pembiayaan Mudarabah BMT Agritama Blitar 
Brosur Pembiayaan Mudarabah BMT alRidho Trenggalek

Brosur Pembiayaan Mudarabah BMT Sahara Tulungagung

Brosur Pembiayaan Mudarabah BMT Syariah Pare Kediri

Brosur Pembiayaan Mudarabah KJKS arRohmah Kota Kediri

Brosur Pembiayaan Mudarabah KSU Syariah Muhammadiyah Kota Blitar

Buku Laporan Pertanggung Jawaban Pengurus Koperasi Syariah Muhammadiyah Blitar Tahun Buku 2012.

Buku Laporan Pertanggung Jawaban Pengurus pada Rapat Anggota Tahunan (RAT) Koperasi Syariah BMT Agritama Srengat Blitar Tahun Buku 2012.

Buku Laporan Rapat Anggota Tahunan (RAT) KJKS ar-Rohmah Kediri Tutup Buku 2012

Buku Laporan Rapat Anggota Tahunan BMT a-Ridho Tugu Trenggalek Tutup Buku 2012, Kamis 24 Januari 2013.

Buku Profil BMT al-Ridho Tugu Trenggalek.

Cecep Maskanul Hakim, http://www.vibiznews.com/1new/kn owledge/syariah/Problem

Pengembangan Produk dalam bank Syariah.pdf

Dharmawangsa, Dedi. (2003). Problematika Seputar Gharar pada Kontrak Mudarabah, (Studi Kasus Realisasi Pembiayaan Mudarabah di BPRS Hareukat Lanbro Aceh Besar)", Tesis, MSI UII Yogyakart.

Karim, Adiwarman A. (2000). Incentive Compatible Constrains for Islamic
Banking: Some Leasson from Bank Muamalat. Conference Papers, Fourth International Conference on Islamic Economics and Banking, Loughborough University, UK.

Khalil, Abdel Fatih AA, Colin Rickwood, dan Victor Muride. (2000). Agency Contractual in Profit Sharing Financing, Islamic Finance: Challenges and Opportunities in The Twenty-First Century, Conference Papers, Fourth International Conference on Islamic Economic and Banking, Loughborough University, UK.

Lawang, Robert MZ. (2007). Membongkar Kepalsuan untuk Mengatasi Kemiskinan”, dalam Muhammad Yunus, Bank Kaum Miskin, Irfan Nasutin (terj.), Tangerang: Marjin Kiri.

Krishnamurti, B. (2005). Pengembangan Keuangan Mikro bagi Pembangunan Indonesia. Media Informasi Bank Perkreditan Rakyat.

Laporan Bank Indonesia Tahun 2009.

Laporan Pertanggung Jawaban Pengurus Koperasi Serba Usaha BMT Syariah Pare Kediri Tutup Tahun Buku 2012.

Laporan Pertanggungjawaban Pengurus dalam Rapat Anggota Tahunan (RAT) Kopsyah BMT Sahara Tulungagung Tahun Buku 2012.

Laporan Pusat Inkubasi Bisnis usaha Kecil (PINBUK) Kabupaten Tulungagung Tahun 2011.

Martowijoyo, S. (2002). Dampak Pemberlakuan Sistem Bank Perkreditan Rakyat terhadap Kinerja Lembaga Pedesaan. Jurnal Ekonomi Rakyat, 1(5).

Robinson, Marguiret S. (1993). Beberapa Strategi yang Berhasil untuk 
Mengembangkan bank Pedesaan: Pengalaman dengan Bank Rakyat Indonesia 1970 - 1990”, dalam Bunga Rampai Pembiayaan Pertanian Pedesaan, Sugianto (Ed.), Penerbit Insitut Bankir Indonesia.

Sumaryadi, I Nyoman. (2005). Perencanaan Pembangunan Daerah Otonom dan Pemberdayaan Masyarakat. Jakarta: Penerbit Citra Utama.

Sumiyanto. (2004). Problem Transaksi Model Mudarabah dalam Lembaga Keuangan Syari'ah, (Studi Kasus Lembaga Keuangan Syari'ah BMTBMT di Yogyakarta). Tesis, MSI UII Yogyakarta.

Udovitch, Abraham L. (2008). Kerjasama Syariah dan Bagi Untung Rugi dalam Sejarah Islam Abad Pertengahan (Teori dan Penerapannya), Syafrudin Arif Marah Manunggal (terj.), Kediri: Qubah.

Waluyo, Bambang. (2016). Implementasi Pembiayaan Mudarabah Pada Bank Syariah Untuk Merealisasikan Tujuan Ekonomi Islam. Jurnal Ekonomi dan Bisnis Islam, 2(2).
Warde, Ibrahim. (1999). The Revitalization of Islamic Profit and Loss Sharing", Proceeding of The Harvard University Forum on Islamic Finance, Oktober 1, Cambridge: Harvard Islamic Finance Information Program Centre for Middle Easter Studies.

Wilson, Terry. (1996). The Empowerment Mannual. London: Grower Publishing Company.

Wirjono, Wilorejo Wirjo. (2005). Pemberdayaan Keuangan Mikro sebagai Salah Satu Pilar Sistem Lembaga Keuangan Nasional: Upaya Konkrit Memutus Mata Rantai Kemiskinan. Jurnal Kajian Ekonomi dan Keuangan, Edisi Khusus Desember.

Yunus, Muhammad. (2007). Bank Kaum Miskin, Irfan Nasutin (terj.), Tangerang: Marjin Kiri. 
